\title{
Two Decades of Doctoral Research in Iowa History, 1961-1980
}

\section{Alan M. Schroder}

Though a substantial proportion of the research in any field of history is disseminated through journal articles and monographs, an equally important indicator of the directions that research in the field is taking can be found in doctoral dissertations. In the two decades from 1961 through 1980 dissertation research in Iowa history moved away from the traditional areas of political and economic history that had been heavily mined in the previous eight decades. Doctoral candidates, instead, exhibited a tendency to expand the topics of study to include a greater proportion of ethnic and cultural areas and to adopt quantitative and behavioral methodologies borrowed from the social sciences.

As historians in the past two decades have turned their attention away from the traditional approaches to the study of politics and government, the number of dissertations on these previously strong areas in the study of lowa history has decreased. For example, only two dissertations on the antebellum period of Iowa politics have appeared. Erling Erickson's 1967 dissertation on the regulation of banking by the Iowa state government before the Civil War blends traditional concerns 
with modern quantitative techniques. ${ }^{1}$ Erickson used scalogram analysis to chart the political alignments of the state political factions that either supported the creation of state-chartered banks of issue or opposed the existence of such banks as a matter of monetary principle. Ronald F. Matthias' study of the Know-Nothing movement in Iowa is a more traditional qualitative examination of the social forces that produced support for the movement. ${ }^{2}$ Matthias concluded that Iowans in 1854 , when the movement began, possessed neither the virulent anti-Catholic nor anti-foreign sentiments that one would normally expect to fuel such a movement. Rather, Matthias found a general sense of unease prompted by the national upheavals in the 1850s, a feeling that was most safely vented in flag-waving Americanism. When antislavery became a politically acceptable issue, Matthias concludes, politicians and popular sentiment turned to attacks on the slave power conspiracy, which had really been much more central to their fears all along.

By the time of the Civil War, Iowa had come to be dominated by the Republican party. But Hubert Wubben's 1963 dissertation on the Copperhead movement in Iowa reveals that Democratic sentiment was far from being eliminated. ${ }^{3}$ Republican dominance removed any hopes the lowa Democrats had for political influence during the war, but antiwar Democrats did organize to protect their rights. Wubben concludes that this did not carry over into offensive pro-Southern activities along the lines of the Knights of the Golden Circle. Rumors of such activity, however, no doubt reinforced lowa Republicans in their dedication to Republican principles, and Iowa and other midwestern congressmen turned to the Radical wing of the Republican party. In a congressional roll-call voting analysis using Guttman scaling and Rice cluster-bloc analysis, Philip Swenson found that midwestern congressmen continued to support

1. Erling Arthur Erickson, "Banks and Politics Before the Civil War: The Case of Iowa, 1836-1865" (University of Iowa, 1967).

2. Ronald F. Matthias, "The Know Nothing Movement in Iowa" (University of Chicago, 1965).

3. Hubert Hollensteiner Wubben, "Copperheads and Unionists: The Trial of the Iowa Democracy, 1860-1865" (State University of Iowa, 1963). 
postwar Radical Reconstructionist measures long after their constituents had lost interest in them in favor of more concrete economic questions. ${ }^{4}$

This does not mean, however, that lowans turned wholeheartedly to gross materialism in the decades after the Civil War. In a study of voting in the lower houses of the Illinois, Iowa, and Wisconsin state legislatures between 1886 and 1895, Ballard C. Campbell found that the lowa legislature did continue to be strongly concerned with socio-cultural issues within the state's borders, issues like prohibition and state supervision of education. ${ }^{5}$ As Iowa's influence on national politics increased late in the century, this concern was carried over to the federal level. Charles H. Clark, for example, noted in a 1966 dissertation that lowa was one of the early leaders in state railroad safety legislation and that Lorenzo S. Coffin, the Iowa Railroad Commissioner, was an important figure in pressing for federal legislation when the interstate character of railroad operations reduced the effectiveness of state laws. ${ }^{6}$ Finally, Iowa politics carried over this concern for social issues into a strong support for the Progressive movement at the turn of the century. One expression of this can be seen in the Des Moines Plan, a commission form of city government that Des Moines popularized following its origination in Galveston, Texas. In a 1976 dissertation, Bradley R. Rice traced the course of the rise and eventual decline of the Des Moines Plan on a national scale between 1901 and 1920.7 He concluded that the commission form of city government represented an advance in many ways, but that it did not produce the efficiency of operation that was a major goal of the Progressives. As a result, it

4. Philip David Swenson, "The Midwest and the Abandonment of Radical Reconstruction, 1864-1877" (University of Washington, 1971).

5. Ballard Crooker Campbell, Jr., "Political Parties, Cultural Groups and Contested Issues: Voting in the Illinois, lowa and Wisconsin House of Representatives, 1886-1895" (University of Wisconsin, 1970).

6. Charles Hugh Clark, "The Railroad Safety Movement in the United States: Origins and Development, 1869 to 1893" (University of Illinois, 1966).

7. Bradley Robert Rice, "The Rise and Fall of the Galveston-Des Moines Plan: Commission Government in American Cities, 1901-1920" (University of Texas at Austin, 1976). 
was often replaced with a city manager form of government that more nearly resembled the businesslike approach that the Progressives were seeking.

After the Progressive era, Iowa's influence on national politics and government waned, but the traditional rural dominance of state politics did not. Two dissertations, one completed in 1964 and the other in 1978, reflect the sharp changes that occurred in this situation in the 1960s. The first, by Charles $W$. Wiggins, describes the very strong influence that the Iowa Farm Bureau Federation had on the state government before the one-man, one-vote legislation of the 1960 s greatly increased the representation of the cities in the state legislature ${ }^{8} \mathrm{~A}$ second change in lowa politics came with the revision of the Democratic party's rules for selecting delegates to its national convention, another product of the political climate of the 1960s. Steven Schier's 1978 dissertation compares the liberalizing effects of these changes on the caucus and convention system in lowa and the primary system in effect in Wisconsin.9 He found that in both states the new rules reduced the party organization's traditional control of the selection process and increased the influence of liberal party activists and interest groups, particularly labor.

Most doctoral research in the past twenty years on the history of Iowa agriculture has treated the subject from two fairly narrow approaches: land tenure and federal farm policy. One exception to this was James Whitaker's study of the beef cattle industry in lowa and Illinois between 1840 and $1900 .{ }^{10}$ Using a traditional approach to the topic, Whitaker traced the development of the industry from a range feeding operation in the 1830 s and 1840 s to a fully-developed fat cattle industry by

8. Charles William Wiggins, "Interest Group Power Within State Legislative Systems: The Case of the Iowa Farm Bureau Federation" (Washington University, 1964).

9. Steven Edward Schier, "The Rules and the Game: Democratic National Convention Delegate Selection in Iowa and Wisconsin, 1968-1976" (University of Wisconsin at Madison, 1978).

10. James Wright Whitaker, "The Rise and Development of Beef Cattle Feeding in Illinois and Iowa, 1840-1900" (University of Wisconsin, 1965). 


\section{Doctoral Research}

1900. This evolution was triggered after the Civil War by an expanded rail network, a growing urban market supplied by largescale packing operations centered at Chicago, and the availability of refrigeration for preserving dressed beef. The lowa and Illinois farmers' willingness to modernize their feeding operations to supply the expanded markets made the two states the center of prime beef production for the nation by 1900 .

Four dissertations trace the changing patterns of land tenure in the state's history. Robert P. Swierenga studied the initial transfer of the public lands from the federal government to speculators and from speculators to producers. ${ }^{11} \mathrm{He}$ found that the process was profitable both for the speculators and for the Iowa economy as a whole. Speculators realized an average of at least a 60 percent compounded annual return on their investment, and they, in turn, pumped millions of dollars of land credit into lowa's frontier economy and provided much-needed tax revenue to finance the construction of the state's roads and schools. Further, Swierenga concluded that their activities did not seriously interfere with the transfer of land to producers.

Seddie Cogswell, in his study of six eastern Iowa counties from 1850 to 1880 , found a system of land tenure in a postfrontier period in which land ownership was still quite open. ${ }^{12} \mathrm{He}$ found that the concept of an "agricultural ladder" - in which farmers move from farm laborers to tenants to landowners in a regular series of steps-to be a valid description of Iowa agriculture at the time. Both foreign-born and native-born farmers gradually accumulated enough capital to begin their own farms. In two studies of recent land tenure patterns, however, Metin Berk and Brian D'Silva concluded that, by the middle of the twentieth century, the agricultural ladder was no longer a valid way of describing the process of land acquisition. ${ }^{13}$ Inheritance had become a much more important

11. Robert Peter Swierenga, "Pioneers and Profits: Land Speculation on the Iowa Frontier" (State University of lowa, 1965).

12. Seddie Cogswell, Jr. "Tenure, Nativity and Age as Factors in Iowa Agriculture, 1850-1880" (University of Iowa, 1972).

13. Metin Berk, "Changing Structure of Iowa Farmland Ownership" (lowa State University, 1971); Brian Christopher D'Silva, "Factors Affecting Farmland Ownership in Iowa" (Iowa State University, 1978). 
means of acquiring land, and tenancy was no longer the path to ownership that it once had been.

In their study of farm policy, researchers have focused on the period between 1900 and 1940, when agriculture was undergoing a modernization process that Iowa farmers found wrenching in many ways. One of the links between Iowa agriculture and federal farm policy in these years is the fact that four lowans served as secretary of agriculture, and all of them have been the subject of dissertations. Willard L. Hoing's 1964 dissertation on James Wilson, who served from 1897 to 1913 , presents the influence of an Iowan on national policy at a time of agricultural prosperity. ${ }^{14}$ This was agriculture's Golden Age, when the secretary of agriculture's prime concern was to increase farm productivity to feed a world market. As a result, Wilson's service consisted mainly of encouraging agricultural production and building the influence of the Department of Agriculture. The next Iowa secretary of agriculture was Edwin T. Meredith, who served in 1920 and 1921, a time when Iowa agriculture was falling into the depression that would haunt it for two decades. Peter L. Petersen's 1971 dissertation on Meredith describes him as a rather unsuccessful dabbler in lowa and national politics and an old-line progressive in an unprogressive time. ${ }^{15}$ Meredith's successor, Henry C. Wallace, is presented by Donald L. Winters as a secretary of agriculture who represented the traditional Republican response of limited federal intervention. ${ }^{16}$ Wallace eventually came to support the McNary-Haugen Bill, but none of the proposed solutions to the agricultural depression of the 1920s, Winters concluded, could have solved the problem, since they did not even envision mandatory production controls. The internationalist position of the fourth secretary of agriculture from lowa, Henry A. Wallace,

14. William Lee Hoing, "James Wilson as Secretary of Agriculture, 1897-1913" (University of Wisconsin, 1964).

15. Peter Lewis Petersen, "A Publisher in Politics: Edwin T. Meredith, Progressive Reform, and the Democratic Party, 1912-1928" (University of lowa, 1971).

16. Donald Lee Winters, "Henry Cantwell Wallace and the Farm Crisis of the Early Twenties" (University of Wisconsin, 1966). 
was the focus of John S. Walker's 1974 dissertation. ${ }^{17}$ Walker identifies Wallace as a lifelong internationalist, with the exception of his brief isolationist stance as the editor of Wallaces' Farmer during the farm depression of the 1920s. As secretary of agriculture from 1933 to 1940, Wallace promoted international cooperation to combat the distress created by what had become a worldwide depression.

Congressional responses to the agricultural depression of the 1920s have also been traced in dissertation research. David B. Webb, in a 1978 dissertation, examined the farmer-backed demand for an inflationary monetary policy in the 1920s that was reminiscent of the free silver issue during the Populist era. ${ }^{18}$ With the efforts of the Farm Bloc in Congress and the support of such organizations as the Grange, the American Farm Bureau Federation, and the Farmers' Union, along with a number of economic theorists, the policy of maintaining strong federal controls over the money supply became an important national issue in the 1920s and continued as such through the Depression. A second attempt at a solution to the problems of the 1920s was the creation of the Federal Farm Board in 1929. David Miller found, however, that its efforts to stabilize farm prices by storing surpluses and to aid the farmer by encouraging farm cooperatives were failures. ${ }^{19}$ Like Donald Winters, Miller concluded that its major success was in demonstrating that farm programs could not raise farm prices without some provision for production controls.

Hugh J. Savage, in a 1961 dissertation, followed the career of the progressive insurgents in Congress who, during the Hoover presidency, broke away from the administration program represented by the Farm Board. ${ }^{20}$ This group, which in-

17. John Samuel Walker, "Henry A. Wallace and American Foreign Policy" (University of Maryland, 1974).

18. David Dean Webb, "Farmers, Professors and Money: Agriculture and the Battle for Managed Money, 1920-1941" (University of Oklahoma, 1978).

19. David Bruce Miller, "Origins and Functions of the Federal Farm Board" (University of Kansas, 1973).

20. Hugh James Savage, "Political Independents of the Hoover Era: The Progressive Insurgents of the Senate" (University of Illinois, 1961). 
cluded Iowa senator Smith Brookhart, took a much more liberal stand on a broad range of social welfare issues than was pursued by the majority of congressmen from either party. Though the progressives were almost all Republicans, Savage concludes that they prepared the way for the great wave of Democratic New Deal legislation, which embodied much of what they had been fighting for from a distinctly minority position.

While most researchers have taken for granted the existence of a farm depression in the 1920s and simply studied the proposed solutions to it, one doctoral candidate, $\mathrm{H}$. Thomas Johnson, challenged the existence of the farm depression itself. ${ }^{21}$ He concluded, first, that trends in farm incomes largely paralleled trends in nonfarm incomes in the 1920s and, second, that the activities labelled farm protests were actually protests by bankers and merchants in small towns who were reacting to the loss of business to the larger towns and cities that came with the new mobility that the automobile offered rural residents. Thompson suggests that historians' misapprehensions have resulted from studying aggregate data that do not single out the economic conditions of homogeneous groups of farmers and businessmen.

Whether or not a farm depression actually existed in the 1920s, American farmers clearly were undergoing a major change in their economic and social status in the years between 1880 and 1930. Deeper ties to the ebb and flow of world commodities markets and the rise of the cities as a competing force in society led inevitably to changes in the farmers' outlook on the world, and these changes have been the subject of at least three dissertations in the past twenty years. N. James Wilson's dissertation-titled, significantly, 'The Farmers' Search for Order (1880-1910)"-describes the positive responses many farmers made to their changing situation. ${ }^{22}$ These included the adoption of modern, scientific farming techniques to increase productivity while lowering costs, the formation of farm

21. H. Thomas Johnson, “Agricultural Depression in the 1920's: Economic Fact or Statistical Artifact?" (University of Wisconsin, 1969).

22. N. James Wilson, "The Farmers' Search for Order (1880-1910)" (University of Oklahoma, 1974). 


\section{Doctoral Research}

cooperatives to combat the economic forces the farmer could not control, and the acceptance of a business approach to farming. Ronald E. Mickel identified the farmers' changing perceptions of their place in American society - what Mickel calls the patterns of agrarian self-consciousness - in the support for farm relief measures in the $1920 \mathrm{~s}^{23} \mathrm{He}$ contrasts the traditional agrarian viewpoint of the short-lived Farm Bloc of the early 1920 s with the more modern viewpoint represented by McNaryHaugenism and the farm cooperative movement later in the decade, which Mickel considers to be attempts to emulate industrial practices. Finally, Don S. Kirschner concluded in his 1964 dissertation that the farmers' suspicions of the expanding cities and the threats of urban life were mitigated in the 1920s by the farmers' own acceptance of such trappings of urban life as the automobile, the radio, and the movies. ${ }^{24}$ While economic competition continued unabated (with the farmer gradually losing ground) the cultural conflicts subsided as farmers began to be more and more like city folk.

As the farmers' economic problems deepened sharply in the 1930s, their protests became more vigorous and, sometimes, violent. One of the best known of the protests, the Farm Holiday movement, was the subject of research by Julius Korgan in 1961 and Lowell K. Dyson in 1968. ${ }^{25}$ This lowa-centered protest movement sought both to halt the dispossession of farmers hard hit by the Depression and to make some move toward mandatory production controls. Though the farmers' actions were more symbolic than substantial, Korgan and Dyson concluded that the Farm Holiday movement did call national attention to the farmers' plight. Its activities were concentrated in the final days of the Hoover administration, however, and when the New Deal farm program went into operation, support for the protest movement waned.

23. Ronald Eldon Mickel, "Patterns of Agrarian Self-Consciousness in the 1920's" (Wayne State University, 1961).

24. Don Stuart Kirschner, "Conflict in the Corn Belt: Rural Responses to Urbanization, 1919-1929" (State University of Iowa, 1964).

25. Julius Korgan, "Farmers Picket the Depression" (American University, 1961); Lowell Keith Dyson, "The Farm Holiday Movement" (Columbia University, 1968). 
While production controls became the New Deal's primary solution to the problem of long-term agricultural surpluses and the low prices that resulted, the alternative of expanding America's foreign markets did gain some attention in the 1930s. In a 1969 dissertation, James B. Beddow followed the changing fortunes of President Franklin D. Roosevelt's program of reciprocal trade agreements. ${ }^{26}$ When FDR introduced the program in March 1934, it sparked an extensive debate in the six midwestern states of North and South Dakota, Minnesota, Nebraska, Iowa, and Kansas. The debate was between an internationalist group who argued that tariff barriers must be lowered in order to open new foreign markets to American agricultural surpluses and a nationalist group who argued that major foreign markets for American farm products no longer existed and that high tariff barriers should be maintained to protect the American market from dumping by other nations. By 1940 , Beddow concluded, the nationalists had largely won in the Midwest, and the reciprocal trade program had become the subject of bitter opposition by midwestern congressmen.

Analyses of a recent farm protest movement can be found in three dissertations on the Iowa-based National Farmers Organization. The first, by Truman D. Wood, examined the NFO's militant early years, which led up to its major 1962 holding action. ${ }^{27}$ The other two studies - by Clara B. Riveland and David A. Carter-examined the NFO's fortunes in its more settled years after 1962 and presented differing views of its success as of the early 1970s. ${ }^{28}$ Riveland concluded that the NFO had failed because it could claim no more than 10 percent of the farm population as members, and that this failure resulted partly from the NFO's own internal wrangling and partly from its

26. James Bellamy Beddow, "Economic Nationalism or Internationalism: Upper Midwestern Response to New Deal Tariff Policy, 1934-1940" (Oklahoma State University, 1969).

27. Truman David Wood, "The National Farmers Organization in Transition" (State University of lowa, 1961).

28. Clara B. Riveland, "An Analysis of the National Farmers Organization's Attempts to Reduce Rhetorical Distance" (University of Minnesota, 1974); David Allen Carter, "The National Farmers' Organization: The Rhetoric of Institutionalization" (University of Iowa, 1976). 
attacks on various segments of its potential public. Carter, in contrast, concluded that the NFO had been successful during the same period, adjusting its approach to the changing agricultural conditions and transforming itself from a protest movement in the 1950s to a stable farm organization by the early 1970s. The contrasting conclusions presented in the Riveland and Carter dissertations may simply reflect contrasting views of what constitutes success for a farm movement.

ThE history of the major cultural groups that made up the Iowa population has been extensively mined by historians since Iowa history became the subject of serious scholarly study in the early twentieth century. Perhaps as a result, historians' research interests in the past twenty years have turned more to smaller cultural groups and communities and to topics that are on the periphery of lowa history. The study of Iowa's oldest cultural group, its Indian population, is a good example of this trend. Though there were numerous archaeological studies of prehistoric Indian occupation of the land that would become Iowa, there was only one dissertation that concentrates on the two tribes most associated with lowa in the historic period: the Sac and Mesquakie. This was Frederick E. McTaggart's folklore study of contemporary Mesquakie stories, a study which is, in fact, as much a study of the Mesquakies' reluctance to discuss the stories with the researcher as it is a study of the stories themselves and what they reveal about Mesquakie life. ${ }^{29}$

Other dissertations on Iowa Indian life deal with topics around the edges of Iowa history. Otis Miller's 1972 study of Indian-white relations in Illinois between 1789 and 1818, for example, includes a discussion of the Sac, Mesquakie, Mascouten, and Potawatomi. ${ }^{30}$ The conflicts that arose between these tribes and the encroaching whites set up the conditions that would

29. Frederick Eugene McTaggart, "Mesquakie Stories: The Teachings of the Red Earth People" (University of Iowa, 1973).

30. Otis Louis Miller, "Indian-White Relations in the Illinois Country, 1789 to 1818 " (St. Louis University, 1972). 
lead to the Indians' expulsion from Illinois in the Black Hawk War and the further loss of part of their land in lowa. Charles Abele studied the Indian council called by the federal government at Prairie du Chien in 1825 and the treaty that resulted from it. ${ }^{31}$ The council represented a thoroughly unsuccessful attempt to bring an end to the intertribal warfare in the Upper Midwest. Its influence on lowa came in the form of a treaty provision that created a boundary between the Sioux and the Sac and Mesquakie in northern Iowa. The tribes ignored the boundary, however, and the government responded by creating a forty-mile-wide Neutral Ground centered on the boundary line and herding the Winnebago into the zone to act as a buffer to keep the tribes apart. While the Neutral Ground was somewhat successful in reducing intertribal warfare, the Grand Indian Council of 1825 and the treaty that resulted from it proved to be an exercise in futility.

The Indian tribes of the Upper Midwest were affected much more seriously by their conflicts with the whites than by those with one another. Gary Anderson's 1978 dissertation discusses the gradual decline of the Santee Sioux as they became increasingly unable to support themselves through hunting and therefore became increasingly dependent on government annuities that could only be obtained by ceding parts of their tribal holdings. ${ }^{32}$ Finally, in the Treaty of 1851 the Santee surrendered the last of their lands in Minnesota and northwest Iowa. The Iowa lands were of secondary importance to the Santee since their real home was in Minnesota, but the process of their gradual decline should be of interest to students of lowa history because it closely parallels the decline of the Sac and Mesquakie in the years between 1833 and 1842, when they also signed away the last of their lowa lands.

For one tribe, the Potawatomi, Iowa was only a stopping point on a westward migration punctuated by a series of treaties. As described by Joseph F. Murphy, a band of

31. Charles A. Abele, "The Grand Indian Council and Treaty of Prairie du Chien, 1825" (Loyola University, 1969).

32. Gary Clayton Anderson, "The Santee Dakota: A Study in Sovereignty and Economic Dependency" (University of Toledo, 1978). 


\section{Doctoral Research}

Potawatomi arrived in southwest lowa in 1835 as the result of their land cession in northern Illinois and southern Wisconsin in 1833. ${ }^{33}$ This was the United Band, which included most of the Prairie Band of Potawatomi and members of the Chippewa and Ottawa tribes as well. They stayed only until 1847, when they moved on to a reservation in Kansas which they shared with other Potawatomi who had already been established in Kansas.

Probably because of the extensive work in the past, only two recent dissertations dealt with the major immigrant groups of the whites who replaced the Indian in lowa. One, by Lowell Soike, is a study of the voting behavior of Norwegian immigrants in Minnesota, Wisconsin, and lowa between 1880 and 1924. ${ }^{34}$ Soike contradicts the emphasis that historians have recently placed on cultural influences on voting. He found that the Norwegians' cultural predispositions could either grow or wither depending on how they fit into the political context in the locality or state in which they settled. Thus, local political influences could offset the pietist-liturgical divisions that ethnocultural historians have stressed.

A second dissertation, by Nancy Derr on the anti-German campaigns in lowa during World War I, deals with a major immigrant group that was forcibly assimilated by government fiat and mob action. ${ }^{35}$ Derr discusses the Americanization process as an expression of nativism, which it obviously was, but she also points out the ties that the anti-German activities had to Progressivism. The Progressive movement included in its membership many people who were, Derr contends, drawn to the movement's elements of coercion and social order. Standardization enforced by the state government was something that business interests in particular were attracted to. By the end of the war, they had achieved victory.

A third dissertation does not deal with a particular immigrant group but does discuss the port of New Orleans as an

33. Joseph Francis Murphy, "Potawatomi Indians of the West: Origins of the Citizen Band" (University of Oklahoma, 1961).

34. Lowell Jerome Soike, "Norwegian-Americans and the Politics of Dissent, 1880-1924" (University of Iowa, 1979).

35. Nancy Ruth Derr, "Iowans During World War I: A Study of Change Under Stress" (George Washington University, 1979). 
entryway for immigrants in general. ${ }^{36}$ This 1978 Louisiana State dissertation by Fredrick Spletstoser discusses the conditions the immigrants met both in New Orleans and on the steamboats that took them upriver. While this study does not discuss lowa directly, it is of interest because of the importance of the "southern route" for channelling immigrants to the Mississippi River towns of Iowa and from there to the interior.

The remaining studies of Iowa's cultural groups concentrate on small colonies or utopian communities. The Mormon settlement at Nauvoo has important implications for Iowa history, both because of its interactions with the early lowa settlements across the Mississippi from Nauvoo and because the expulsion of the Mormons from Nauvoo eventually led to a strong Mormon representation in towns in southern lowa. Robert B. Flanders' study, "Nauvoo: Kingdom on the Mississippi," is a traditional treatment of the settlement as it was under Mormon occupation. ${ }^{37}$ A second dissertation, by Kenneth $O$. Luke, follows the history of Nauvoo after the expulsion of the Mormons. ${ }^{38}$ This period included the influx of Icarian colonists, who also had strong ties to Iowa history.

The Icarians were followers of Etienne Cabet, who outlined his plan for a utopian socialist society in a novel entitled Voyage en Icarie. When their settlement in Nauvoo met the same antipathy from local residents that the Mormons had encountered, the Icarians moved on to southwest Iowa to establish a colony near Corning. The history of the Corning settlement has received extensive treatment by historians, but two dissertations written in the $1960 \mathrm{~s}$ fill in the European background of the Icarian movement. Janice Fotion studied Cabet's plans for a communal settlement, a "Republic of Virtue," and contrasted his abilities as an organizer of the movement in

36. Fredrick Marcel Spletstoser, "Back Door to the Land of Plenty: New Orleans as an Immigrant Port, 1820-1860," 2 vols. (Louisiana State University and Agricultural and Mechanical College, 1978).

37. Robert Bruce Flanders, "Nauvoo: Kingdom on the Mississippi" (University of Wisconsin, 1964).

38. Kenneth Otto Luke, "Nauvoo, Illinois, Since the Exodus of the Mormons, 1846-1973" (St. Louis University, 1973). 
France with his deficiencies as a practical leader of the colony that came to America. ${ }^{39}$ The European background of Icarianism is also discussed by Christopher Johnson in his dissertation on the fortunes of the movement in France between 1839 and $1848 . .^{\circ 0}$ In contrast to the usual portrait of Cabet as a bumbling visionary, Johnson concludes that, in France at least, he proved to be a practical and effective political organizer and propagandist. Whichever treatment is more correct, Cabet's ideas and his actions in France and America provide important background information for understanding the Icarian settlement in lowa.

Another utopian colony in Iowa, called the Iowa Pioneer Phalanx, was established near Oskaloosa in 1843. It followed the ideas of Charles Fourier, another French theorist, and it was one of about two dozen phalanxes formed in the United States in the 1830s and 1840s. Carl Guarneri's 1979 dissertation on Fourierism provides an interesting discussion of the way in which the European doctrines of Fourier were modified in the American environment. ${ }^{41}$ Guarneri presents American Fourierism as a practical, conservative approach to socialism in which Fourier's vast plans were boiled down to a system that its followers believed would realize - not overthrow - the American ideals of democracy, Christianity, and missionary nationalism. The Iowa Pioneer Phalanx was not, however, a particularly successful example of these ideals; it dissolved by mutual consent of the colonists in 1845 .

A much more successful colony in Iowa was the Amana settlement, which was founded in 1855 and which did not dissolve its communal relationship until 1932. Though the Amana Colonies have been the subject of extensive historical writing in the twentieth century, Robert Clark offers a fresh

39. Janice Clark Fotion, "Cabet and Icarian Communism" (University of lowa, 1966).

40. Christopher Howard Johnson, "Etienne Cabet and the Icarian Communist Movement in France, 1839-1848" (University of Wisconsin, 1968).

41. Carl Joseph Guarneri, "Utopian Socialism and American Ideas: The Origins and Doctrine of American Fourierism, 1832-1848" (Johns Hopkins University, 1979). 
viewpoint, discussing the colonies' history in terms of historical geography. ${ }^{42}$ An equally successful cultural group in lowa, though they did not form a single community, is the lowa Amish. The Amish have sought to remain, in varying degrees, separate from the rest of lowa society in the areas of technological and social change. Though this has traditionally been a peaceful separation, one aspect of Amish society that has caused some conflict is that of education. Donald P. Hayes's dissertation discusses the struggle that developed in the 1960s between the Amish, who contended that state education requirements violated their religious principles, and the State of Iowa, which charged that the Amish authorities' failure to meet state requirements violated the rights of Amish children. ${ }^{43}$ In the end, the Amish won their case, and the precedent that was established has at least the potential for influencing the resolution of future disputes concerning the conduct of private schools in the state.

IOWA HAS SHARED in the historical profession's resurgence of interest in the study of local communities in the past twenty years. There have been studies made from both the traditional narrative, nonquantitative viewpoint and quantitative studies using social science concepts as an interpretive framework. Examples of the traditional approach to local history are Faye E. Harris' study of Keokuk from 1820 to 1866 and George A. Boeck's study of Burlington from 1833 to $1866 .{ }^{44}$ Both studies seek to interpret the towns' economic, political, and social developments in the context of Turner's frontier thesis. Harris concluded that the Turnerian model of social equality, political democracy, and economic opportunity fit the situation of

42. Robert Edwin Clark, "A Cultural and Historical Geography of the Amana Colony, lowa" (University of Nebraska at Lincoln, 1974).

43. Donald Paul Hayes, "The Iowa Amish and Their Education" (University of Iowa, 1972).

44. Faye Erma Harris, "A Frontier Community: The Economic, Social, and Political Development of Keokuk, Iowa, from 1820 to 1866" (State University of lowa, 1965); George Albert Boeck, "An Early lowa Community: Aspects of Economic, Social and Political Development in Burlington, Iowa, 1833-1866" (State University of lowa, 1961). 
Keokuk very well. Boeck concluded that, while Burlington offered substantial economic opportunity and a fairly open leadership group, it never went through the standard Turnerian sequence in the frontier process. Instead, it was part of a "bourgeois frontier" that skipped the most primitive stages of the development process. Boeck's study has also been supplemented by Willard Toussaint's biography of Charles Mason, a Burlington businessman who participated in many of the economic ventures described in Boeck's dissertation. ${ }^{45}$

Two others studies of the early history of Iowa's Mississippi River towns are Loren Horton's study of town planning and architectural styles in Dubuque, Davenport, and Muscatine between 1833 and 1860 and Philippe Oszuscik's history of architectural patterns and urbanization in Davenport in the nineteenth century. ${ }^{46}$ Horton found the three river towns to be remarkably undistinctive in their approach to town planning and in the architectural styles residents employed. Even the very large German and Irish immigrant populations failed to give the towns distinctive tones. Oszuscik's dissertation carries Davenport's growth through the period when the railroad brought very rapid economic development and a corresponding geographic expansion to the city. But he, too, found that Davenport developed no distinctive architectural tone.

Davenport and its surrounding rural area in Scott County were also the subject of a quantitative analysis by Mark Friedberger in a 1973 dissertation. ${ }^{47}$ Using a sample of 5900 males listed in manuscript Iowa state censuses between 1885 and 1925, Friedberger performed a cohort analysis of the social structure of the urban and rural environments. Many of Friedberger's findings are none too surprising - that farmers

45. Willard Irving Toussaint, "Biography of an Iowa Businessman: Charles Mason, 1804-1882" (State University of lowa, 1963).

46. Loren Nelson Horton, "Town Planning, Growth, and Architecture in Selected Mississipi River Towns of Iowa, 1833-1860" (University of Iowa, 1978); Philippe Oszuscik, "A History of the Architecture and Urbanization of Nineteenth Century Davenport, Iowa," 3 vols. (University of lowa, 1979).

47. Mark William Friedberger, "Cornbelt and River City: Social Change in a Midwest Community, 1885-1930" (University of Illinois at Chicago Circle, 1973). 
tended to have larger families than urban dwellers, for example, and that wealth was more evenly distributed in the rural areas than in Davenport. Friedberger concluded that the outbreak of socialism in Davenport during World War I was the product of the essentially settled character of the population by that time.

Another modern form of methodology - the use of collective biography to study elite groups - was applied to the four Great Plains cities of Tulsa, Kansas City, Omaha, and Des Moines by Reid A. Holland in a 1972 dissertation. ${ }^{48}$ Using biographical information published in the 1920s, Holland found that the elites in each of the cities were very similar in their backgrounds. They tended to come from rural backgrounds, but they were well-educated professionals.

Like the Holland study, most of the recent studies of Iowa communities have found them to be fairly typical midwestern cities. William Silag's study of Sioux City and its hinterland between 1854 and 1900, however, found it to be distinct from communities like Iowa's Mississippi River cities that grew up as suppliers to, and exporters from, the agricultural regions immediately surrounding them. ${ }^{49}$ In its early years, Sioux City was a market center that served a distant region of the Upper Missouri long before it drew significantly on the agricultural commodities produced in the surrounding area. Because of its strategic location on the Missouri River, Sioux City became an important link in the steamboat trade as early as the 1850s, and it expanded this market role as railroads entered the area in the 1860 s and 1870s. But it was not until the 1870 s and 1880 s that Sioux City merchants sought to promote the agricultural exports of the city's own hinterland.

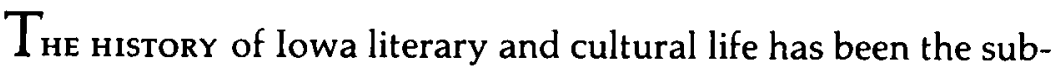
ject of a number of dissertations in the past twenty years. The 1970s saw a widespread interest in the works of Hamlin Garland, an interest that produced three dissertations that ex-

48. Reid Allen Holland, "Urban Frontier Leadership" (Oklahoma State University, 1972).

49. William Silag, "City, Town, and Countryside: Northwest lowa and the Ecology of Urbanization, 1854-1900" (University of Iowa, 1979). 
amine his ideas from three different viewpoints. Richard Potter's 1971 study of Garland dealt with his short fiction as a form of historical source material. ${ }^{50}$ Recognizing the limitations of fiction that result from its imaginative basis, Potter still recommends works like Garland's as a means of describing the broad features of a culture. Catherine E. Raymond cited Garland's work, on the other hand, as a means of understanding human * perception of the natural environment, in Garland's case the environment of the midwestern prairie. ${ }^{51}$ Raymond describes the broad, empty land of the prairie as a landscape that challenged the people who settled it to create order upon it, and she suggests that this reaction may have been unique to the prairie environment. Frances W. Kaye found in Garland's fiction the image of the woman of the prairie frontier as a "reluctant westerner," someone who sought to recreate the civilized culture she had left behind. ${ }^{52}$ In fact, Kaye considers Garland to be the most faithful and thorough chronicler of this type of pioneer woman.

The works of Iowa authors Emerson Hough and Herbert Quick have also been analyzed in recent dissertations. In her 1978 dissertation, Annette McElhiney cited Hough and Quick as examples of late nineteenth-century popular novelists who presented a largely stereotypical image of the pioneer woman as a preserver of civilized values. ${ }^{53}$ Richard Ferguson's biographical study of Quick examines his fiction in the context of his advocacy of the agrarian reforms and improvements in rural life that were part of the late nineteenth- and early twentieth-century reform movements. ${ }^{54}$ Finally, a more critical view of Herbert Quick as an author can be found in Frederick

50. Richard Harold Potter, "Rural Life in Populist America: A Study of Short Fiction as Historical Evidence" (University of Maryland, 1971).

51. Catherine Elizabeth Raymond, "Down to Earth: Sense of Place in Midwestern Literature" (University of Pennsylvania, 1979).

52. Frances Weller Kaye, "The Roles of Women in the Literature of the Post Civil War American Frontier" (Cornell University, 1973).

53. Annette Bennington McElhiney, "The Image of the Pioneer Woman in the American Novel" (University of Denver, 1978).

54. Richard Whitt Ferguson, "Herbert Quick and the Search for a New American Frontier: A Biography" (University of Minnesota, 1977). 


\section{The Annals of Iowa}

G. Morain's 1970 Yale dissertation, in which he concludes that Quick's typically narrow midwestern provincialism and shortsighted agrarianism prevented him from understanding areas of society that were not part of the rural midwestern context and made his writing irrelevant to the new industrial America in which he lived. 55

Though the frontier novel and short story are the forms most associated with Iowa's literary history, the state's urban landscape has also produced writers who have been the subject of study in recent years. Research has been concentrated on the group of writers who were connected with Davenport in the early twentieth century. One of these, Susan Glaspell, was the subject of a critical biography by Marcia Noe in $1976 . .^{56}$ Glaspell spent her early years as a writer in Davenport and Des Moines, then moved with George Cram Cook to Greenwich Village. There, she joined the group of writers known as the Radicals, which included Floyd Dell. Dell had also spent part of his early life in Davenport. The Radicals' revolt against the Genteel Tradition (which Dell, Glaspell, and Cook had all presumably encountered in Davenport) has been chronicled in dissertations by Frank A. Stricker, Robert E. Humphrey, and William P. Dunkel. ${ }^{57}$ Another member of the Davenport group, Harry Hansen, was the subject of a 1979 dissertation by William $\mathrm{H}$. Roba. ${ }^{58}$ Though Hansen was known primarily as a newspaper columnist, Roba's discussion of Hansen's contacts with Floyd Dell, Arthur D. Ficke, and other Davenport writers helps to explain the literary environment that influenced their early lives.

55. Frederick Garver Morain, "Herbert Quick, lowa Agrarian" (Yale University, 1970).

56. Marcia Ann Noe, "A Critical Biography of Susan Glaspell" (University of lowa, 1976).

57. Frank A Stricker, “Socialism, Feminism, and the New Morality: The Separate Freedoms of Max Eastman, William English Walling, and Floyd Dell, 1910-1930" (Princeton University, 1974); Robert Edward Humphrey, "Children of Fantasy: The Rebels of Greenwich Village, 1910-1920" (University of Iowa, 1975); William Paul Dunkel, "Between Two Worlds: Max Eastman, Floyd Dell, John Reed, Randolph Bourne and the Revolt Against the Genteel Tradition" (Lehigh University, 1976).

58. William Henry Roba, "A Literary Pilgrim: Harry Hansen and Popular American Book Reviewing, 1915-1945" (University of lowa, 1979). 


\section{Doctoral Research}

Iowa's cultural history has also been analyzed from an institutional standpoint. Charles L. Geroux's dissertation on the history of the theatres and theatrical activity in Dubuque from 1837 to 1877 combines the study of architectural design with the cultural functions associated with each form. ${ }^{59}$ Geroux describes, for example, the outdoor "Gardens" and "Concert Saloons" in connection with distinctly German theatrical performances. Similarly, James M. Johnson's history of the Tri-City Symphony offers an example of the interaction between cultural institutions and the communities they serve. ${ }^{60}$ The Tri-City Symphony's fortunes, Johnson found, have tended to rise or fall in response to local economic conditions and to the degree to which the symphony served the cultural needs of the Tri-City area.

In addition to providing the environment for cultural activities, lowa also has sought actively to promote them. Two examples of this can be found in dissertations by Leland $\mathrm{H}$. Sherwood and Stephen Wilbers. ${ }^{61}$ Sherwood studied the federally-sponsored community art centers that arose in Iowa during the Depression. The centers, which were part of the New Deal's Federal Art Project under the Works Progress Administration, supported the state's cultural environment at a time when it would otherwise have suffered severe cutbacks. The Sioux City Art Center, in fact, provided a model for such centers for the nation as a whole. Stephen Wilbers studied a more recent cultural institution that had an even greater national reputation: the Iowa Writers' Workshop. Wilbers traces the Workshop's founding (a much debated point among Iowa's literary historians) and its development into what he calls "the finest program in the country" in its field.

59. Charles L. Geroux, "The History of Theatres and Related Theatrical Activity in Dubuque, Iowa, 1837-1877" (Wayne State University, 1973).

60. James Melvin Johnson, "The History of the Tri-City Symphony Orchestra of Davenport, Iowa, Rock Island and Moline, Illinois" (University of lowa, 1976).

61. Leland Harley Sherwood, "The Federal Sponsored Community Art Centers of lowa as a Part of the New Deal" (Indiana University, 1973); Stephen McCoy Wilbers, "Emergence of the Iowa Writers' Workshop" (University of Iowa, 1978). 
Many of the Depression-era murals sponsored by the Federal Art Project through institutions like the Sioux City Art Center embodied the style and subject of the Regionalist school, which flourished in the 1930s. A leader of this school was Iowa painter Grant Wood, who-along with Wood's fellow Regionalists Thomas Hart Benton and John Steuart Curry - was the subject of Martha O. Cruz's 1975 dissertation. ${ }^{62}$ Cruz concluded that, rather than merely provincial chroniclers of quaint scenes from everyday life, the Regionalists were leaders in a long-overdue movement to provide a distinctly American art form independent of the constricting European styles.

From the standpoint of another area of cultural life, Iowa has also produced, or been the home of, several figures in the intellectual history of the nation. An early proponent of what has come to be called secular humanism, Abner Kneeland, was the subject of a 1971 dissertation by Roderick French. ${ }^{63}$ French studied the period when Kneeland underwent a personal transformation from religious commitment to strong secular criticisms of injustice in American society. Kneeland found that his views brought him prosecution in Boston (the home of such supposedly liberal figures as William Ellery Channing, Orestes Brownson, and William Lloyd Garrison) so he moved west to found Salubria, a short-lived utopian colony in Iowa. French concludes that Kneeland's intellectual development paralleled the transformation of American thought in the early 1800s.

John Coleman found a similar progression in the thought of Iowan Jesse Macy in the late nineteenth and early twentieth centuries. ${ }^{64}$ In Macy's case, the change was from genteel liberalism (expressed in the Social Gospel movement) to an appeal to the professional classes for their participation in a scientific approach to government during the Progressive Era.

62. Martha O. Cruz, "The Regionalist Triumvirate and the "American Program': Thomas Hart Benton, Grant Wood and John Steuart Curry" (St. Louis University, 1975).

63. Roderick Stuart French, "The Trials of Abner Kneeland: A Study in the Rejection of Democratic Secular Humanism" (George Washington University, 1971).

64. John Park Coleman, "In Pursuit of Harmony: A Study of the Thought of Jesse Macy" (University of Iowa, 1968). 


\section{Doctoral Research}

Another lowan who represented the reform spirit of the Progressive Era was Carrie Chapman Catt, who was the subject of a 1973 Syracuse University dissertation by David Katz.65 Catt's most prominent work was in the field of women's suffrage, but Katz concentrated on her efforts to promote international peace, which she became involved with during World War I. Katz stresses the connections that existed between the suffrage movement, a nonviolent movement for social justice within the nation, and the peace movement, which extended the concept of social justice to the international level.

Few American historians have done more to make historical writing a form of literature than Iowa historian Carl Becker. Becker has been studied by three doctoral researchers in the past two decades, each of whom dealt with Becker's emphasis on the human side of history and of historical writing. David E. Herold classed Becker with Samuel Eliot Morison, Douglas Southall Freeman, and Bernard DeVoto in the group of historians who maintained a nineteenth-century concern for narrative history in the midst of the twentieth century's emphasis on objectivity. ${ }^{66}$ Becker and the others, Herold maintains, sought to retain the wide general reading audience that historical literature had had in the nineteenth century and that it was losing in its coldly objective, even scientific, writing in the twentieth. As a relativist, Becker contended that the content of historical works cannot be separated from the social and intellectual context in which the works are prepared. Another student, Lowell Blaser, continues this point by comparing Becker to Henry Adams, both of whom criticized the movement toward a scientific approach to history in the late nineteenth and early twentieth centuries. ${ }^{67}$ Becker denied that truly scientific historical writing was possible, and in doing so he followed

65. David Howard Katz, "Carrie Chapman Catt and the Struggle for Peace" (Syracuse University, 1973).

66. David Edward Herold, "A Species of Literary Lion: Essays on Morison, Freeman, DeVoto, and Becker and the Writing of History" (University of Minnesota, 1973).

67. Lowell Kent Blaser, "Between Science and Art: Henry Adams, Carl Becker, and History in America" (University of North Carolina at Chapel Hill, 1977). 
the later thinking of Adams. Blaser also appends a discussion of the broader implications of the division between the "two cultures" in historical writing that is implicit in the rise of quantitative, behavioral, and psychological historical studies. Finally, Harold Bauman stresses in his dissertation that Becker's relativism was an outgrowth of his central analogy of history as human memory. ${ }^{68}$ Becker was concerned with the psychological causes of historical events, but he was equally concerned with the psychological conditions through which historians screen their perceptions of the past. These psychological conditions, Becker contended, are formed by the social and intellectual contexts in which the historians live.

The picture of Iowa's education system that emerges from the dissertation research of the past twenty years is that of a solid but conservative system that has changed slowly and reluctantly. Carroll Engelhardt's examination of the role Iowans expected their common school system to play in the period from 1876 to 1921 reveals that the schools were essentially expected to train good citizens who would fit quietly into a peaceful, harmonious, and stable society. ${ }^{69}$ This was especially true of the nineteenth-century outlook, but it was also true even when the more progressive idea that education should benefit the individual began to be accepted in the twentieth century. The new approaches were supported, Engelhardt maintains, simply because they would help to train even better citizens. This conservative view of lowa education is enhanced by Frances Stein's study of the educational philosophy of Iowan Ernest Horn. ${ }^{70}$ Stein presents Horn as a follower of the progressive ideas of John Dewey, but a conservative follower with much more

68. Harold Bauman, "The Historiography of Carl L. Becker" (State University of Iowa, 1964).

69. Carroll Lee Engelhardt, "The Common School and the Ideal Citizen: lowa, 1876-1921" (University of lowa, 1969).

70. Frances Jordan Stein, "Ernest Horn's Ideas on Education within the Context of the Progressive Education Movement in America" (University of lowa, 1973). 


\section{Doctoral Research}

modest expectations for the use of the school as an instrument of social reform.

The same view emerges from research on the local and state supervision of Iowa's schools. Wayne Truesdell's study of Iowa school organization found only very slow change in the patterns of governance. ${ }^{71}$ Using Arnold Toynbee's challenge-and-response approach to the study of historical change, Truesdell found that in lowa the challenge of new educational techniques was followed by a response in terms of state legislation only after a very long lag time. In fact, the legislative acts usually just codified educational practices that had long been in use by the time of their passage. Richard N. Smith found the same pattern in the functioning of the Iowa Department of Public Instruction, with the DPI pursuing the improvement of rural education (an early twentieth-century crusade) well into the 1950s and largely ignoring the quality of urban education. ${ }^{72}$ James Meiborg even found the architecture of Iowa's school buildings constructed between 1919 and 1969 to be conservative. ${ }^{73}$ Early in the century, lowa school buildings were still being modeled after churches and, even though school buildings became a distinct architectural form in the 1920s, it was not until after World War II that lowa schools were planned specifically for the programs they were intended to support.

The state colleges and universities have apparently had a somewhat more liberal history. James E. Gilson's dissertation on the changes in student life at the University of Iowa between 1880 and 1900, for example, describes a modernization process in which a pietistic lifestyle was replaced by a more wordly, materialistic orientation. ${ }^{74}$ The main expressions of this change, Gilson contends, came in an increased influence on the part of

71. Wayne Palmer Truesdell, "A History of School Organization and Superintendence in lowa" (University of Iowa, 1965).

72. Richard Newton Smith, "The Development of the Iowa Department of Public Instruction, 1900-1965" (University of lowa, 1967).

73. James Edward Meiborg, "A Fifty-Year Period in the Evolution of Schoolhouse Design and Construction in Iowa: 1919-1969". (University of lowa, 1970).

74. James Edward Gilson, "Changing Student Lifestyle at the University of Iowa, 1880-1900" (University of Iowa, 1980). 
fraternities and intercollegiate athletics. A more substantial form of modernization in the University at the turn of the century was the rise of graduate training. Carl Seashore, the University's Dean of the Graduate College, was a leader in the professionalization of graduate training not only at the University of Iowa, but in the nation as a whole. His career, chronicled by Lewis L. Jones, included a successful effort to have creative works accepted for a doctoral degree. ${ }^{75}$ This was an important step in encouraging the arts in a university environment, and it made possible the creation of programs like the Iowa Writers' Workshop.

The strongest ties between the university system and the state's schools have always been, of course, through the universities' teacher-training programs. The programs at Iowa State University in Ames and at the Iowa State Normal School at Cedar Falls have been traced in dissertations by L. David Weller, Jr., and Clarence T. Molen, Jr. ${ }^{76}$ The state's goal in both programs seems to have been to educate a sufficient number of teachers to fill the hundreds of schools established around the state, but also to not over-educate them. Weller's study of Iowa State, which covers the period from 1869 to 1968 , describes a program that followed the university's traditional emphasis on vocational education, particularly in agriculture, home economics, and business and industry. The various teachertraining programs were administered through the individual departments, however; the College of Education was not established until 1968. At the State Normal School and its successor, the Iowa State Teachers College, Iowa's traditionally conservative approach to education was given full scope. As described by Clarence Molen, the Normal School spent its early years, from 1876 to the 1880 s, in a simple effort to survive as an

75. Lewis Lester Jones, "Carl Emil Seashore: Dean of the Graduate College of the University of Iowa, 1908 to 1936, Dean Pro Tempore, 1942 to 1946: A Study of His Ideas on Graduate Education" (University of Iowa, 1978).

76. L. David Weller, Jr., "A History of Undergraduate Teacher Education Programs at Iowa State University, 1869-1968" (Iowa State University, 1975); Clarnece Theodore Molen, Jr., "The Evolution of a State Normal School Into a Teachers College: The University of Northern Iowa, 1876-1016" (University of Iowa, 1974). 
institution. When its existence was finally assured, it gradually expanded into a full four-year college, accomplishing this by about 1900. But when the state government sought to coordinate the activities of the three state institutions by creating a State Board of Education in 1909, one of the board's first acts was to discontinue all courses at the Teachers College beyond the sophomore year. Apparently there was some concern that lowa's prospective teachers were in danger of becoming more educated than they needed to be. Fortunately, the public outcry at this step backward was great enough to force the board to withdraw its decision. By 1916, when Molen's dissertation closes, the college had been assured of its continued existence as a four-year institution.

The dissertations in lowa history completed between 1961 and 1980 were not part of any grand plan for historical research. As a group, however, they did expand the traditional boundaries of Iowa history into new areas of social and cultural history and often examined lowa history for the first time from a quantitative or behavioral viewpoint. While many have been published as journal articles or books, many others have remained in their original form. In either form they stand as signposts of the directions of lowa historical research. 
Copyright of Annals of Iowa is the property of State of Iowa, by \& through the State Historical Society of Iowa and its content may not be copied or emailed to multiple sites or posted to a listserv without the copyright holder's express written permission. However, users may print, download, or email articles for individual use. 